\title{
Study on the Reform of Administrative System in Social Management of China
}

\author{
Ying. Li \& Ailian. Liu \\ School of Marxism, Hohai University, Nanjing, Jiangsu, China
}

\begin{abstract}
At present there are still many problems of the administrative system in Chinese social management. From the aspect of the theory and practice of administrative system reform, the transformation of government functions and correctly handle the relationship between government and market are the basic targets, creating a service-oriented government is the macro goal of administrative system reform. The main way of the reform are: turning government management concept, transforming government functions, promoting the public service system, further innovation and so on.
\end{abstract}

KEYWORD: Administrative management system; Service-oriented government; Social management

\section{GENERAL INSTRUCTION}

The reform of the administrative system is an necessary way to adapt and the promote the process of China's social management, and the key point is the construction of service-oriented government. The reform of the administrative system must be based on the task of building service-oriented government, to reform from the system (mechanism), functions (role), process (process), technology (method) and the central and local governments. To perfect Chinese social management through the construction of service-oriented government, namely the people can have the right of education, employment, medical treatment, pension and living residence, gradually achieving the goal of equalization of basic public service, implementing the innovation of public service system, improving the way of public services, strengthening the construction of public service facilities, and gradually form the basic public service system which benefits the whole people(HU, 2008).

\section{THE DEVELOPMENT OF INNOVATION OF ADMINISTRATIVE SYSTEM IN CHINA}

\subsection{The background}

In the past thirty years, public sector reform has become a global trend. The new public management is not entirely a pursuit of efficiency, but put forward a number of dynamic and flexible strategy for the government on how to provide public service more effectively. Global government reform not only due to the objective factors such as globalization, informatization, technological progress, economic and social development, financial crisis, the traditional bureaucratic inefficiencies, but also mainly due to the citizen's dissatisfaction, the crisis of confidence in the government, the public wants to improve the methods and quality for the people the service, which wants the government to provide more quality services, effectively expanding the service scope and. Citizens also wants the government to improve public service capacity, so as to provide more high quality service at low cost.

In the new period, the basic contradiction of Chinese society has not changed, but the form changes greatly, facing two major problems: one is the rapid growth of economic and resource environment; the other is the imbalance between urban and rural regional development. There is a shortage in the supply of basic public service and public products. These two contradictions have become to be the problems that need to be solved in urgent. What should be done to solve these two contradictions is the reform of the administrative system, basing on the building of service-oriented government (LIU, 2002).

After the reform and development of thirty years, the enterprise has become the main body of the market, and the basic role of the market in the allocation of resources has been formed, thus if the government continues to serve as the subject of the social and economic life, the needs of economic development cannot be satisfied. Therefore, the 
transition from economic-oriented type to the public service-oriented government and solving the deep contradiction between economic and social must be carried on.

\subsection{The status of development}

Since the reform and opening up, China has carried out five institutional reforms. After the reform, the functions of government have been changed to a certain extent, the institutions and staff have been optimized and standardized, system and mechanism innovated effectively, administrative efficiency improved, providing an important institutional guarantee and support for the reform and opening up and socialist modernization construction. Last several reforms' goals were more clear and specific, and the reforms has reflected the concept of improvement way of government social management, not only conforming to the international trend of the reform of the administrative system but also adapting to the request of social development at that time in China. Especially in the recent three times, the reforms focused on the transformation of government functions, the separation of government from enterprises, innovation of administrative examination and approval system, the reform of government institutions, the construction of scientific and democratic decision-making mechanism and the adjustment of the structure of state-owned economy strategic, the construction of administrative legal system and other series of reforms, which was the beginning of the major transformation of government's administration system. Meanwhile, the local government reform was also in constant exploration and practice, the attempt to reform and innovate occurred.

The 17th National Congress of the CPC proposed to accelerate the reform of the administrative system, building a service-oriented government, which puts forward new requirements for the transformation of China's administrative system reform and the government's function. China's reform and opening up is now facing two major problems: one is the function of the government, the other is the political system, which are both involved in the reform of administrative system in China. At present, China's administrative system still follow the structure of that in age of planned economy, and the enterprise's operation is in accordance with the law of market economy, which is the biggest institutional obstacles that the reform encounters.
3 THE MAIN RPOBLEMS OF THE GOVERNMENT'S ADMINISTRATIVE SYSTEM REFORM IN CHINA

\subsection{Unreasonable structure of government's institutes}

The number of the departments that have been set up is big, especially that of the department of economic and social management, and the phenomenon of economic and social affairs are occupied by the government is quite serious. There is still a considerable distance with the establishment of the limited government called for by market economy, and the transformation of government functions is quite slow. The cost of the management is high. Some scholars pointed out that the scale of China's central government was 2-3 times more than some countries. In accordance with the proportion indicators of civil servants and the GDP, the number of civil servants China greatly exceed that of the developed countries, which is nearly 20 times (from the personnel's expense and the ratio of GDP, China is 39 one staff / millions of dollars, much higher than the developed countries, the America is 2.31, and Japan is 1.38) (LI, 2007). The cost of the management is dozens of times more than the west strong countries. Another study showed that, between 1999 and 2005 the affect of the administrative cost of China on economic growth was minus $1.73 \%$ ( CHEN, 2008).

The functional division of responsibilities and duties has existing, and the departments' coordination is ineffective, the distribution of the institutes is too concentrated or scattered. The configuration of decision, execution and supervision is not scientific. Some managing functions such as decision-making, execution and supervision are concentrated in one sector, lacking of power balance, which is not conducive to the construction of a incorrupt and honest administration.

\subsection{The service-oriented government has not been fully built}

The construction of China's service-oriented government is still in the spontaneous state, and there is no unit clear requirement. Some local governments and institutes did not carry out this work, or just a mere formality. Administrative reform is not initiative, and is a reform under external pressure, lacking overall planning. At present, there is a gap between the ability of Chinese government public service and the people's increasing demand for it, many local governments simply focus on GDP growth, in the pursuit of image project, performance engineering, and their social management and public service functions are weak. The development of social undertakings lags behind; lots of important problems relate to the vital interests 
of the people don't get timely and effective solution, seriously damaging the relationship between the public and the government.

The local administrative system reform does not adapt to the construction of service-oriented government. Due to the fast economic development in the eastern region of China, the development of administrative reform is more effective, and some backward areas have not been substantive reformed, basically following the mode of old management, and the level of government management is low, becoming the barrier to economic development and social progress.

\subsection{Faulty social management and public service}

There are some outstanding issues about people's livelihood; problems of system supply cannot be ignored. Formulation and policy design in public service system did not fully concern the vulnerable groups. In China's social management, the transformation of government functions and the input of the people's livelihood are not enough, lacking the correct view on people's livelihood, causing a shortage of livelihood security system.

\section{THE SUGGESTIONS ON THE WAY OF CHINA'S CURRENT ADMINISTRATIVE SYSTEM}

\subsection{Change the idea of social management}

In social management, the traditional governmentoriented, power-oriented idea has existed for a long time, and citizen-oriented, social-oriented idea of service government has just formed, and obviously at a disadvantage. Changing the management idea has become the most important problem.

The government is the institute to supply public services for other social bodies, and must regard the interests of people as the highest interest, improving public service quality and public satisfaction. At the same time, the government should also soberly aware that the ability and the power are limited, and the government will also appear failure phenomenon. The monopoly situation must be changed, and the government should give some right to back to the people. In the social management, concept of integrity must be established, meeting the need of the healthy operation of the market economy, enhancing the government's credibility.

\subsection{Transform the function of the government}

History of administrative system reform since the reform and opening up in China clearly draw a line, which is the government transform from the control to management to service-oriented type. For half a century, although there are still different views of the people's talk about the role of government, one thing is clear, namely the power-oriented mode has failed, but without the government's development will also fail, meaning no effective government, no development achieved (SHI, 1997). The focus of work of the government should be transferred to the macro management which includes planning, mastering policy, information guidance, coordination, service and supervision. The government should deal with the relationship among the enterprise, market, society, namely depart the government from the enterprise, reducing the intervention to the enterprise and strengthening the guidance and service; give full play to the basic role of the market in the allocation of resources, and the government's supervision should regulate market behavior, rectify the market economic order, and improve unified, open, fair market system; clear the government's responsibility on social and people, establishing a new system of social services, such as social service commitment system, opening government system, solving the reasonable problems put forward by the citizens.

\subsection{Improve the basic public service system}

In addition to putting more funds into the field of public service and providing more public resources to rural areas, less developed areas where lack the public service, the system of public service should be improved, establishing the social participating mechanisms of public service. As the decision maker, the government has the absolute authority of state power, but as a service provider, the government is a choice, because it do not have a monopoly of to whom the services be provided. For example, the health care system was established to provide the equal service for all citizens. However, over the years, it has facing increasingly fierce competition with the private medical service providers (SHIRK, 2004). At the same time, the government should promote the performance evaluation which takes the public service as the main content, having the choices of the typical regions and typical services (such as education, health care and social security) to evaluate the quantity and quality of public service. In the west, the most common form is the local government especially the city government to do the survey of citizen satisfaction or community attitudes every year, mainly from the view of satisfaction and citizens' demands, providing needs assessment for the future planning. In China, Beijing City Public Service Commission also commissioned zero company conducted an assessment of public service satisfaction. 


\subsection{Reform personnel system and promote legal management}

Deng Xiaoping pointed out: "the correct political route must be guarantied by a correct organizational route. Whether Chinese can develop fast and better, the socialist reform and opening up can insist, economy can develop faster and the country can keep in long period of stability, in a sense, the key point is people."(DENG, 2008) Therefore, the cadre personnel system should be reformed deeply, creating an opening, equal, competing, preferred employment environment, and effectively solve the problem of classification management of cadres, improving the scientific and reasonable salary distribution system, making appointment system of leading cadres of the statutory tenure and tenure target responsibility system, improving the democratic appraisal and recommend in cadres selection, reforming and perfecting the posts and ranks of cadres system combining, reasoning distribution system, and effectively solve the problem of unfair distribution, insufficient incentive and weak constraint, leading that all levels of government is not only able to retain talent, but also can give full play to the role of government civil servants. Government officials' basic quality to social image must have new changes.

Legal administration is the core concept of government management, is a basic principle of government administrative operation. Governments at all levels should not only strengthen the idea, but also be good at using laws and regulations to deal with and solve the problems in government affairs, especially which relate to the vital interests of the people. Administrative law system which adapts to both Chinese conditions and international rules of administrative law should be further established and improved, and relevant laws and regulations should be formulated and improved. It is important to strengthen the supervision of administrative law enforcement, realizing the law to be obeyed, the law to be strict enforced and the illegal behavior to be punished. Make sue the reform policy, development policy is closely integrated with the legislative decision-making, promoting reform of the administrative system by the guidance of law and guaranteeing the healthy development of the socialist market economy.

All in all, Chinese government's socialist construction is a progress of managing more effectively and better. However, current Chinese social management still need to be improved, facing various problems, such as unreasonable structure of the institutes, lack of idea of service-oriented, faulty public service and so on. Therefore, the administrative system need further reform, focusing on the changing of managing idea, the government's function, improving basic service system, reforming personnel system and legal management. Chinese social management will be improved, stepping forward in harmonized social construction.

\section{ACKNOWLEDGEMENT}

Foundation item: The postgraduate's innovating project of the common university in Jiangsu province (2013-B13020286)

\section{REFERENCES}

[1] HU, J.T. 2008. Focusing on the construction of serviceoriented government. Sina Web.

[2] LIU, R.X. 2002. Service-oriented government-the target chosen by Chinese government under background of globalization. Chinese Administration.7:5.

[3] LI, Z. 2007. The experts analysis about super-ministry system of central institutes: Power balancing will be the focus of refom. Sina Web.

[4] CHEN, J. 2008. Super-ministry system refom schem may be sunmitted to NPC and CPPCC. Sina Web.

[5] SHI, C. 1997. The report of World Bank development-the government in the world of refom. Beijing: Chinese Financial and Economic Publishing House, 4: 17.

[6] A, SHIRK. 2004. Agencis, authorities and other government bodies-the process of exploring the principles. Beijing: CITIC Publishing House, 6: 22-26.

[7] DENG, X.P. 2008. Deng Xiaoping authology( the third volume). Beijing: People Publishing House. 